Authors' contribution/

Wkład autorów:

A. Zaplanowanie badań/

Study design

B. Zebranie danych/

Data collection

C. Analiza statystyczna/

Statistical analysis

D. Interpretacja danych/

Data interpretation

E. Przygotowanie tekstu/

Manuscript preparation

F. Opracowanie

Literature search

G. Pozyskanie funduszy/

Funds collection piśmiennictwa/

\section{POSSIBILITY OF INDUSTRIAL HEMP CULTIVATION IN AREAS OF HIGH NATURE VALUE}

\author{
MOŻLIWOŚCI UPRAWY KONOPI WŁÓKNISTYCH NA OBSZARACH \\ PRZYRODNICZO CENNYCH
}

\author{
Bogumiła Zadrożniak ${ }^{(\mathrm{A}, \mathrm{B}, \mathrm{D})}$, Katarzyna Radwańska ${ }^{(\mathrm{E}, \mathrm{F})}$, \\ Alicja Baranowska ${ }^{(\mathrm{E}, \mathrm{F})}$, Iwona Mystkowska ${ }^{(\mathrm{E}, \mathrm{F})}$
}

Pope John Paul II State School of Higher Education in Biała Podlaska Państwowa Szkoła Wyższa im. Papieża Jana Pawła II w Białej Podlaskiej

Zadrożniak B., Radwańska K., Baranowska A., Mystkowska I. (2017), Possibility of industrial hemp cultivation in areas of high nature value/ Możliwości uprawy konopi włóknistych na obszarach przyrodniczo cennych. Economic and Regional Studies. Vol. 10, No. 1, pp.114-127. https://doi.org/10.2478/ers-2017-0009

\section{REVIEW ARTICLE}

JEL code: Q13

Submitted:

December 2015

Accepted:

December 2016

\section{Summary}

Subject and purpose of work: The aim of this work is to present the possibilities of cultivating varieties of industrial hemp which are registered in Poland in areas of high nature value.

Materials and methods: This work is a type of overview; it describes characteristic features of areas of high nature value. It also presents specific biological properties, cultivation and agrotechnical requirements, as well as the versatility of industrial hemp usage.

Results: This study demonstrated considerable importance of industrial hemp in developing areas of high nature value, in accordance with the idea of sustainable development.

Conclusions: Due to the specific biological properties of industrial hemp, its low cultivation and agrotechnical requirements and lack of the need to use pesticides, industrial hemp can be successfully grown in areas of high nature value.

Tables: 0

Figures: 3

References: 24

Keywords: areas of high nature value, cultivation, industrial hemp

\section{Streszczenie}

ARTYKUŁ PRZEGLĄDOWY

Klasyfikacja JEL: Q13

Przedmiot i cel pracy: Celem pracy jest przedstawienie możliwości
odmian konopi włóknistych na obszarach przyrodniczo cennych.

Materiały i metody: Praca ma charakter przeglądowy, dokonuje charakterystyki obszarów przyrodniczo cennych. Przedstawiono także specyficzne właściwości biologiczne, wymagania uprawowe i agrotechniczne oraz wszechstronne kierunki użytkowania konopi włóknistych.

Wyniki: W pracy wykazano duże znaczenie konopi włóknistych w zagospodarowaniu obszarów przyrodniczo cennych zgodnie z realizacją idei zrównoważonego rozwoju.

Wnioski: Konopie włókniste ze względu na specyficzne właściwości biologiczne, niskie wymagania uprawowe i agrotechniczne oraz brak konieczności stosowania pestycydów z powodzeniem mogą być uprawiane na obszarach cennych przyrodniczo.

Słowa kluczowe: obszary przyrodniczo cenne, uprawa, konopie włókniste

Address for correspondence/ Adres korespondencyjny: dr inż. Bogumiła Zadrożniak, dr inż. Katarzyna Radwańska, dr inż. Alicja Baranowska, dr Iwona Mystkowska, Państwowa Szkoła Wyższa im. Papieża Jana Pawła II w Białej Podlaskiej, Wydział Nauk Ekonomicznych i Technicznych, Sidorska 95/97, 21-500 Biała Podlaska, Polska; tel.: +48 8334499 05; e-mail: bzadrozniak@wp.pl

Journal indexed in/ Czasopismo indeksowane w: AgEcon Search, AGRO, BazEkon, Index Copernicus Journal Master List, ICV 2015: 81,26; Polish Ministry of Science and Higher Education 2016: 9 points / AgEcon Search, AGRO, BazEkon, Index Copernicus Journal Master List ICV 2015: 81,26; Ministerstwie Nauki i Szkolnictwa Wyższego 2016: 9 punktów. Copyright: (C) 2016 Pope John Paul II State School of Higher Education in Biała Podlaska, Bogumiła Zadrożniak, Katarzyna Radwańska, Alicja Baranowska, Iwona Mystkowska. All articles are distributed under the terms of the Creative Commons Attribution-NonCommercial-ShareAlike 4.0 International (CC BY-NC-SA 4.0) License (http://creativecommons.org/licenses/by-nc-sa/4.0/), allowing third parties to copy and redistribute the material in any medium or format and to remix, transform, and build upon the material, provided the original work is properly cited and states its license. 


\section{Introduction}

The idea of sustainable development is one of the most important concepts in the field of civilizational changes which occurred in the second half of the twentieth century. This concept was a response to many years of experience in implementing various socio-economic development strategies, and especially to their environmental impacts (Poskrobko 2011). The best way to preserve areas of high nature value is to protect them and grant conservation status to them. It is generally understood that areas of high nature value are treated as a synonym of protected areas (Idole, Bines 2004). However, not all areas which are valuable in terms of the natural environment are protected and not all of them can be protected in the future. Owing to the new approach to the functioning of the natural world, the need for a different treatment of the biological diversity problem was observed. It is not areas alone which should be the object of protection, but the processes of matter, energy and information flows in the biosphere. Ensuring free movement of these factors is possible through creating a system of areas of high nature value with various levels of protection, linked together in a network. The management of the natural environment is carried out within the limits of particular ecosystems, which undergo various transformations as a result of conditions being transformed within them and in their surroundings. One of the major environmental problems in Europe, associated with environment management, is the decrease of biodiversity in the last few decades. The effects of the decrease of biodiversity are already present today and will be even more perceptible in the near future. Taking into account high expenses of undertaking measures in this respect, and sometimes their impossibility, this trend must be counteracted. Biodiversity is protected in a special way in areas of high nature value. These areas are extremely important for the proper functioning of the entire natural environment on the domestic and global scale. The development of civilization and economy to date exposes the natural heritage of Poland to progressive degradation. Measures contributing to the protection of the natural environment should be based on the protection of ecosystems and rational management of areas of high nature value. Nature conservation should not be determined by any administrative boundaries. It is only effective if it encompasses the entire natural environment, rather than only its individual elements (i.e. certain species of plants, animals, ecosystems or protected areas). The system of areas of high nature value ensures combining the most valuable areas in terms of natural, aesthetic and cultural qualities into one coherent organism. At the same time, such a system can contribute to the more effective implementation of development processes, resulting in the further development of civilization (Zielińska 2013).

\section{Wstęp}

Idea zrównoważonego rozwoju należy do najważniejszych koncepcji w zakresie przemian cywilizacyjnych, które nastąpiły w drugiej połowie XX wieku. Koncepcja ta była reakcją na wieloletnie doświadczenia w realizacji różnych strategii rozwoju społeczno - ekonomicznego, a zwłaszcza na ich środowiskowe efekty (Poskrobko 2011). Najlepszym sposobem zachowania wartościowych przyrodniczo terenów jest objęcie ich ochroną i nadanie im statusu ochronnego. $\mathrm{W}$ powszechnym rozumieniu tereny cenne przyrodniczo są traktowane jako synonim obszarów chronionych (Idole, Bines 2004). Nie wszystkie jednak wartościowe pod względem cech środowiska przyrodniczego obszary są i mogą być w przyszłości objęte formami ochrony. Dzięki nowemu podejściu do funkcjonowania przyrody dostrzeżono potrzebę innego traktowania problemu zachowania różnorodności biologicznej. Przedmiotem ochrony powinny być nie tyle obszary, co procesy przepływu materii energii i informacji w biosferze. Zapewnienie swobodnego przepływu tych czynników jest możliwe poprzez stworzenie systemu obszarów przyrodniczo cennych o różnym stopniu ochrony, połączonych ze sobą w sieć. Gospodarowanie środowiskiem przyrodniczym odbywa się w granicach poszczególnych ekosystemów, które ulegają różnorodnym przemianom w wyniku przekształcających się warunków w nich samych i w ich otoczeniu. Jednym z ważniejszych problemów środowiskowych w Europie, łączących się z gospodarowaniem jest zmniejszanie się bioróżnorodności w ostatnich kilku dziesięcioleciach. Skutki utraty bioróżnorodności obecne są już dziś, a jeszcze silniej odczuwalne będą w najbliższej przyszłości. Uwzględniając kosztowność działań w tym zakresie, a czasem ich niemożliwość należy przeciwdziałać tej tendencji. Bioróżnorodność chroniona jest w szczególny sposób na obszarach przyrodniczo cennych. Obszary te są niezmiernie ważne dla prawidłowego funkcjonowania całego środowiska przyrodniczego w skali kraju, jak i całego świata. Dotychczasowy rozwój cywilizacyjny i gospodarczy naraża dziedzictwo przyrodnicze Polski na postępującą degradację. Działania przyczyniające się do ochrony środowiska przyrodniczego powinny polegać na ochronie ekosystemów oraz racjonalnym gospodarowaniu na obszarach przyrodniczo cennych. Ochrona przyrody nie powinna być wyznaczona żadnymi granicami administracyjnymi. Jest ona skuteczna tylko wtedy, kiedy obejmuje całe środowisko przyrodnicze, a nie pojedyncze jego elementy ( $\mathrm{tj}$. określone gatunki roślin, zwierząt, ekosystemy czy obszary chronione). System obszarów przyrodniczo cennych zapewnia połączenie w jedną spójną całość obszarów najcenniejszych pod względem walorów przyrodniczych, estetycznych i kulturowych. Jednocześnie taki system może się przyczynić do efektywniejszej realizacji procesów gospodarowania, a w efekcie do dalszego rozwoju cywilizacyjnego (Zielińska 2013). 


\section{The specific features of areas of high nature value}

There is no uniform definition assigned to the concept of areas of high nature value, which has not been definitively established yet. In the subject literature, an area of natural value is described as an area which is characterized by significant natural abiotic and/or biotic values, most often sensitive to transformation and threatened by transformation (Andersen et al. 2003, Ciszewska 2008). A broadly understood definition of areas of high nature value is based on the natural and economic criteria (Jalinik 2002). According to the natural criterion it is "an area of land or sea with high biodiversity and with natural and cultural resources associated with it, which deserves being kept in a relatively unchanged state". However, according to the economic criterion, it should be understood as an "area whose biological and landscape diversity is or may be (by selecting appropriate methods and directions) a dominant factor of economic activity or an area which significantly limits the conventional forms of economic management." According to Łuszczyk (2011), while classifying a given area as one of natural value, an area of high biodiversity, slightly or not transformed by man, where the level of pollution does not interfere with the functioning of the original ecosystem, is the most important one. These are particularly areas that meet the aesthetic, scientific, cultural and recreational needs of human population. As the author notes, this approach determines the development of human activity, which ensures protection of the natural environment. Environmentally valuable areas should contribute to socio-economic development, provided the environmental qualities are preserved. This definition refers not only to certain features of these areas, but also to the way of utilising them. The area of high nature value is an area of high environmental value and high biodiversity, which should be or is protected by law. The elements of the natural environment occurring in this area are the key factor for the balanced and sustainable development and preservation of biodiversity. At the same time, the development of traditional industry and agriculture is limited in this area. Environmentally valuable areas are protected by law due to their unique and incomparable value. It arises from the necessity of preserving the natural heritage for future generations and maintaining ecological processes and ecosystem stability (Hajduk 2011). Very often the term "an area of high nature value" is used as a synonym for protected areas. However, are the areas of high nature value really protected areas? The abovementioned definitions indicate that areas of high nature value are also defined as areas performing mainly natural functions, which are crucial for maintaining ecological balance (Ciszewska 2008). Steiner (1999) defines areas of high nature value as the areas which are sensitive to negative influences of the environment, which include: unstable soils, strongly inclined slopes, flood plains and habitats of rare

\section{Specyfika obszarów cennych przyrodniczo}

Pojęcie obszarów przyrodniczo cennych nie ma jednolitej definicji i nie zostało ostatecznie ustalone. W literaturze przedmiotu terenem cennym przyrodniczo określany jest obszar cechujący się znaczącymi wartościami przyrodniczymi abiotycznymi i/lub biotycznymi, najczęściej wrażliwy na przekształcenia i zagrożony przekształceniami (Andersen i in. 2003, Ciszewska 2008). Szeroko rozumiana definicja obszarów przyrodniczo cennych opiera się na kryterium przyrodniczym i ekonomicznym (Jalinik 2002). Według kryterium przyrodniczego jest to „obszar lądu lub morza o wysokiej różnorodności biologicznej, a także związanych z nim zasobów naturalnych i kulturowych, zasługujący na utrzymanie w stanie względnie niezmienionym". Natomiast według kryterium ekonomicznego należy rozumieć pod tym pojęciem „obszar, którego różnorodność biologiczna i krajobrazowa stanowi lub może stanowić (przy doborze właściwych metod i kierunków) dominujący czynnik działalności gospodarczej lub w istotny sposób ogranicza konwencjonalne formy gospodarowania". Według Łuszczyka (2011), klasyfikując dany obszar jako cenny przyrodniczo największe znaczenie ma rejon o dużej bioróżnorodności w niewielkim stopniu bądź wcale nie przekształcony przez człowieka, na którym poziom zanieczyszczeń nie zakłóca funkcjonowania pierwotnych ekosystemów. W szczególności będą to tereny, które zaspokajają estetyczne, naukowe, kulturowe oraz wypoczynkowe potrzeby człowieka. Jak zaznacza autor, takie podejście determinuje rozwój aktywności człowieka, która zapewnia ochronę środowiska przyrodniczego. Obszary przyrodniczo cenne powinny służyć rozwojowi społeczno - gospodarczemu, pod warunkiem zachowania trwałości walorów środowiska. Definicja ta wskazuje nie tylko na pewne cechy tych obszarów, ale także na sposób ich wykorzystywania. Obszar przyrodniczo cenny jest terenem o dużej wartości przyrodniczej i wysokiej bioróżnorodności, który powinien być lub jest objęty ochroną prawną. Występujące na nim elementy środowiska naturalnego stanowią podstawowy czynnik zrównoważonego i trwałego rozwoju oraz zachowania bioróżnorodności. Jednocześnie na tym obszarze ulega ograniczeniu rozwój tradycyjnego przemysłu i rolnictwa. Obszary przyrodniczo cenne ze względu na swoją niepowtarzalną i niewymierną wartość podlegają ochronie prawnej. Wynika ona z konieczności zachowania dziedzictwa przyrodniczego dla przyszłych pokoleń oraz utrzymania procesów ekologicznych i stabilności ekosystemów (Hajduk 2011). Niejednokrotnie pojęcie „obszar przyrodniczo cenny” jest stosowane jako synonim terenów chronionych. Czy jednak rzeczywiście tereny cenne przyrodniczo to tereny chronione? Wcześniej przytoczone określenia wskazują, że tereny cenne przyrodniczo są także definiowane jako obszary pełniące głównie funkcje przyrodnicze, które są kluczowe dla zachowania równowagi ekologicznej (Ciszewska 2008). Steiner (1999) definiuje obszary przyrodniczo cenne jako tereny wrażliwe na negatywne wpływy środowiska i zalicza do nich: 
plant and animal species. Environmentally valuable areas are extremely varied, depending on the dominant natural function they perform, regulation of hydrographic conditions, provision of habitats for plants and animals and their ability to migrate. Therefore, pieces of land, characterized by diverse properties with regard to habitat, plant assemblage, soil properties, groundwater retention etc., will constitute such areas. Areas of high nature value differ in the degree of anthropogenic transformation (from almost natural to semi-natural) and in the degree of resistance to anthropogenic threats (from sensitive to those with significant resistance). Areas of natural value are more or less isolated. Very often these are areas typical of or characteristic for a particular region, or unique and rare. Kistowski (2007) expressed an opinion that the properties of valuable natural areas go far beyond the administrative definition of protected areas. All the protected areas are certainly valuable, but not all areas of high nature value are covered by various forms of protection. As synonyms for areas of high nature value, the following terms are most often given: valuable natural areas, sites of natural importance, areas with valuable natural areas, sites of special natural values (Wolski 2002). Some species of plants, due to their specific biological properties, agrotechnical demands and versatility of their usage, are considerably important for the realisation of the idea of sustainable development. The definition of sustainable development was first given in the report "Our Common Future", which was created in 1987, under the aegis of the World Commission on Environment and Development of the United Nations and under the leadership of Mrs Gro Harlem Brundtland. In this report sustainability was defined as "development that meets the needs of the present without compromising the ability of future generations to meet their own needs." In Polish legislation, in Article 3 of the Environmental Protection Law of 27 April 2001 sustainable development is understood as a "socio - economic development, in which there is a process of political, economic and social integration, while maintaining natural balance and permanence of basic natural processes in order to guarantee the possibility of satisfying the basic needs of communities or citizens of both the present generation and future generations." Therefore, sustainable development consists in the permanent improvement of the quality of life for present and future generations through the development of an appropriate balance between the three types of capital: economic, human and natural (Piontek 2002). The aim of this study is to demonstrate the possibility of cultivating industrial hemp in areas of high nature value, with considerations for the specific nature of the crop and its economic importance. niestabilne gleby, silnie nachylone stoki, tereny zalewowe, siedliska rzadkich gatunków roślin i zwierząt. Tereny przyrodniczo cenne są bardzo zróżnicowane w zależności od dominującej funkcji przyrodniczej jaką pełnią, regulacji stosunków wodnych, zapewnienia miejsca bytowania roślin i zwierząt oraz możliwość ich przemieszczania się. Będa to zatem tereny charakteryzujące się różnorodnymi właściwościami w zakresie siedliska, zbiorowiska roślinnego, właściwości gleb, zalegania wód podziemnych itd. Obszary przyrodniczo cenne różnią się stopniem przekształcenia antropogenicznego (od niemal naturalnych po półnaturalne) i stopniem odporności na zagrożenia antropogeniczne (od wrażliwych po te o znacznej odporności). Obszary przyrodniczo cenne są mniej lub bardziej izolowane. Niejednokrotnie to obszary typowe, czy charakterystyczne dla danego regionu lub unikalne i rzadkie. Kistowski (2007) wyraził opinię, że właściwości obszarów przyrodniczo cennych znacznie wykraczają poza administracyjne określenie terenów chronionych. Wszystkie tereny chronione są $\mathrm{z}$ pewnością wartościowe, ale nie wszystkie tereny cenne przyrodniczo są objęte różnymi formami ochrony. Jako synonimy terenów cennych przyrodniczo najczęściej podawane są takie określenia jak: tereny wartościowe przyrodniczo, tereny mające znaczenie przyrodnicze, tereny o cennych wartościach naturalnych, tereny o szczególnych wartościach przyrodniczych (Wolski 2002). Niektóre gatunki roślin dzięki specyficznym właściwościom biologicznym, wymaganiom agrotechnicznym i wszechstronnym kierunkom użytkowania wykazują duże znaczenie w realizacji idei zrównoważonego rozwoju. Definicja zrównoważonego rozwoju po raz pierwszy została podana w raporcie „Nasza Wspólna Przyszłość”, który powstał w 1987 roku, pod egidą Światowej Komisji Srodowiska i Rozwoju Organizacji Narodów Zjednoczonych i przewodnictwem Pani Gro Harlem Brundtland. W Raporcie tym zdefiniowano zrównoważony rozwój jako: „rozwój odpowiadający potrzebom dnia dzisiejszego, który nie ogranicza zdolności przyszłych pokoleń do zaspokajania własnych potrzeb". W ustawodawstwie polskim, w artykule 3 Ustawy Prawo Ochrony Środowiska z dnia 27 kwietnia 2001 roku zrównoważony rozwój rozumie się jako „rozwój społeczno - gospodarczy, w którym następuje proces integrowania działań politycznych, gospodarczych i społecznych, z zachowaniem równowagi przyrodniczej oraz trwałości podstawowych procesów przyrodniczych, w celu zagwarantowania możliwości zaspakajania podstawowych potrzeb poszczególnych społeczności lub obywateli zarówno współczesnego pokolenia, jak i przyszłych pokoleń". Rozwój zrównoważony polega zatem na trwałej poprawie jakości życia współczesnych i przyszłych pokoleń poprzez kształtowanie właściwych proporcji pomiędzy trzema rodzajami kapitału: ekonomicznym, ludzkim i przyrodniczym (Piontek 2002). Celem opracowania jest przedstawienie możliwości uprawy konopi włóknistych na obszarach przyrodniczo cennych z uwzględnieniem specyfiki uprawy i znaczenia gospodarczego. 


\section{Biological characteristics of industrial hemp}

The species of industrial hemp (Cannabis sativa L.) belongs to the hemp family (Cannabaceae), to the genus Cannabis. Hemp is considered to be a plant easily adaptable to changing conditions during vegetation. Within the species there are many types, forms and varieties with significant biological and morphological differences and varying economic value. In terms of different environmental conditions to which industrial hemp had to adapt while spreading into different climatic zones, we divided them into: the northern varieties - dwarf types, with a short growing season; the southern ones - high-growing, with a long growing season; and intermediate ones. There is also another division of cannabis species: Cannabis Sativa, containing less than $0.2 \%$ of the hallucinogenic substance THC (tetrahydrocannabinol) and Cannabis Indica, which have intoxicating properties (containing more than $0.2 \%$ of THC). Moreover, among all the varieties of cannabis we can distinguish dioecious and monoicous ones. The cultivated hemp grows as annual, anemophilous and dioecious plants. Male (staminate) and female (pistillate) specimens of dioecious hemp are subject to different modes of development. The vegetation period of staminates ends approximately 4 weeks earlier, which causes a number of complications, with regard to both agricultural machinery and processing. In order to eliminate these problems, simultaneously ripening monoicous industrial hemp cultivars have been bred, yielding a homogeneous raw material and a higher seed crop.

\section{Root system}

The main root of Cannabis plants is a taproot. The roots of cannabis, as long as they are not hindered by the ground water level or the type of substratum, reach up to $2-3 \mathrm{~m}$ in depth. This enables them to collect water from deeper layers of the soil and survive periods of drought. On mineral soils the main mass of roots develops at a depth of $20-40$ $\mathrm{cm}$. On peat soils the main root rarely penetrates to a depth of more than $30-40 \mathrm{~cm}$, while the main mass of roots develops at a depth of $10-20 \mathrm{~cm}$. In meliorated peat soils the rooting depth reaches only $50-60 \mathrm{~cm}$.

\section{Stalk}

Cannabis plants have only one stem. Branching at the base of the stem is a unique phenomenon, and branching in the upper part of the plant forms a panicle. Depending on the conditions of vegetation, industrial hemp reaches from 1 to 5 $\mathrm{m}$ in height. The height of the stem is an important morphological feature, which determines the crop of straw and depends on the density of sowing and the characteristics of the cultivar. Cannabis is a "fibreyielding plant", which means that the content of easily extractable fibre is sufficiently large and the quality high enough to make the extraction and processing of the fibre profitable. As a result of processing the straw of the monoicous varieties of industrial hemp registered in Poland $25-30 \%$ of grain and $70 \%$ of

\section{Charakterystyka biologiczna konopi}

Gatunek konopie siewne (Cannabis sativa L.) należy do rodziny konopiowatych (Cannabaceae), rodzaju Cannabis. Konopie uważane są za roślinę łatwo przystosowującą się do zmiennych warunków podczas wegetacji. W obrębie gatunku występuje wiele typów, form i odmian o znacznych różnicach biologiczno - morfologicznych i o różnej wartości gospodarczej. Pod względem zróżnicowanych warunków środowiskowych, do których konopie musiały się przystosować rozprzestrzeniając się w różnych strefach klimatycznych konopie dzielimy na: północne - niskopienne, o krótkim okresie wegetacji, południowe - wysokie, o długim okresie wegetacji oraz pośrednie. Istnieje również inny podział konopi na: konopie włókniste, zawierające poniżej $0,2 \%$ substancji halucynogennej THC (tetrahydrokannabinolu) i konopie haszyszowe, o właściwościach odurzających (zawierające powyżej 0,2\% THC). Ponadto we wszystkich typach konopi można wyodrębnić konopie dwupienne i jednopienne Konopie uprawne są rośliną jednoroczną, wiatropylną, rozdzielnopłciową. U konopi dwupiennych osobniki męskie (płaskonie) i osobniki żeńskie (głowacze) są roślinami podlegającymi odmiennym prawom rozwojowym. Płaskonie okres wegetacji kończą o około 4 tygodnie wcześniej, co powoduje szereg komplikacji, zarówno w sprzęcie, jak i w przerobie. W celu wyeliminowania tych problemów wyhodowano jednocześnie dojrzewające konopie jednopienne dające jednolity surowiec oraz wyższy plon nasion.

\section{System korzeniowy}

Konopie posiadają korzeń główny typu palowego. Korzenie konopi o ile nie przeszkodzi im poziom wody gruntownej lub rodzaj podłoża sięgają do 2 $3 \mathrm{~m}$ głębokości. Pozwala im to na pobieranie wody z głębszych warstw gleby i przetrwanie okresów suszy. Na glebach mineralnych główna masa korzeni rozwija się na głębokości $20-40 \mathrm{~cm}$. Na glebach torfowych korzeń główny rzadko przenika na głębokość niższą niż 30 - $40 \mathrm{~cm}$, natomiast główna masa korzeni rozwija się na głębokości $10-20 \mathrm{~cm}$. Na zmeliorowanych torfach głębokość korzenienia dochodzi zaledwie do $50-60 \mathrm{~cm}$.

\section{Łodyga}

Rośliny konopi mają tylko jedną łodygę. Rozgałęzienia u podstawy są zjawiskiem wyjątkowym, natomiast rozgałęzienia w górnej części rośliny tworzą wiechę. W zależności od warunków wegetacji konopie osiągają od 1 do $5 \mathrm{~m}$ wysokości. Wysokość łodygi jest ważną cechą morfologiczną, która decyduje o plonie słomy i zależy od zastosowanej gęstości siewu oraz właściwości odmiany. Konopie są „roślinami włóknodajnymi", co oznacza, że zawartość łatwego do wyizolowania włókna w roślinie jest dostatecznie duża, a jego jakość na tyle wysoka, że wydobycie i przerób włókna są opłacalne. W wyniku przerobu słomy zarejestrowanych w Polsce jednopiennych odmian konopi włóknistych uzyskuje się 25 - 30\% włókna i około $70 \%$ paździerzy. Włókno w łodydze 
chaff are obtained. The fibre in the industrial hemp stem is not uniformly distributed, with most of it in the central part of the stem, and the quantity and quality depending on the weather during the growing season and agrotechnical conditions. Hemp fibre is of complex structure. It is made up of the rings of primary and secondary fibre. The primary fibre is formed throughout the growing season and is spread over the entire length of the stem. The secondary fibre is formed later: from the beginning of the gynoecium formation to ripening. The secondary fibre, in terms of quality, is significantly worse than the primary one, less resistant and during mechanical processing it is usually transformed into short fibres.

\section{Leaves}

Cannabis leaves have opposite arrangement, short peduncle, palmately compound shape with about three to seven lance-shaped leaflets. Individual leaflets are up to $10 \mathrm{~cm}$ long and $2 \mathrm{~cm}$ wide. They are characterized by a serrate rim and acuminate tip. Leaves on both sides are covered in rough hairs, especially densely on the undersurface and on the venation. The hairs on industrial hemp leaves are single, simple, widened at the base. At the base of the leaves there are filamentary bracts up to $1 \mathrm{~cm}$ in length. Female plants have thicker foliation than male ones.

\section{Inflorescence}

Cannabis inflorescence forms a raceme. Flower development begins in the lower parts of the inflorescence to end with flower development at the tip. Male flowers are located on a hanging pedicle and consist of five yellow - green thecae of elongated form. From the time of male flowers formation to the time of pollination onset, 4 to 7 days pass. Male flowers in full bloom yield a mass of pollen which can be carried by wind over a distance of a few kilometres, so seed plantations should be established with maintaining appropriate spatial isolation. Female flowers do not feature perianth and are anemophilous. A monocarpous gynoecium has two stigmas. After about four weeks of pollination female flowers produce fruits called achenes.

\section{Seeds}

Cannabis seeds (fruit) are single-seed achenes. They have a spherical-oval shape, and are slightly flattened laterally. The average weight of 1000 seeds of southern cannabis varieties is $18-26 \mathrm{~g}$; in intermediate cannabis varieties, it is $12-18 \mathrm{~g}$ and in the case of wild cannabis it is $8-12 \mathrm{~g}$. The seeds are embedded in the inflorescence. They ripen progressively, starting from the bottom of the raceme. The colour of the seeds changes during ripening from green to grey-green or dark brown. Cannabis seeds contain about $25 \%$ protein, $35 \%$ fat and $25 \%$ carbohydrates, as illustrated in Figure 1 (Grabowska, Heller 2009). konopi rozmieszczone jest nierównomiernie, najwięcej znajduje się go w środkowej części łodygi, a jego ilość i jakość zależą od przebiegu warunków atmosferycznych w okresie wegetacji oraz od czynników agrotechnicznych. Włókno konopne ma budowę kompleksową. Składa się z pierścieni włókna pierwotnego i wtórnego. Włókno pierwotne tworzy się przez cały okres wegetacji i rozłożone jest na całej długości łodygi. Włókno wtórne formuje się później: od początku tworzenia się zawiązków kwiatowych do okresu dojrzewania. Włókno wtórne pod względem jakości jest znacznie gorsze od pierwotnego, mniej wytrzymałe i w trakcie przerobu mechanicznego przechodzi zazwyczaj do włókna krótkiego.

\section{Liście}

Liście konopi są naprzeciwległe, krótkoogonkowe, dłoniasto sieczne, o trzech do siedmiu lancetowatych odcinkach. Poszczególne listki posiadają do 10 cm długości i $2 \mathrm{~cm}$ szerokości. Cechują się piłowanym brzegiem i zaostrzonym wierzchołkiem. Liście z obu stron są szorstko owłosione, szczególnie gęsto od spodu i na nerwach. Włoski na liściach konopi są pojedyncze, proste, u nasady rozszerzone. U nasady liści znajdują się nitkowate przylistki o długości do 1 $\mathrm{cm}$. Rośliny żeńskie posiadają gęstsze ulistnienie niż osobniki męskie.

\section{Kwiatostan}

Kwiatostanem konopi jest wiecha. Rozwój kwiatów rozpoczyna się w dolnych częściach kwiatostanu, a kończy rozwojem kwiatów przy wierzchołku. Kwiaty męskie znajdują się na zwisającej szypułce i składają się z pięciu żółto - zielonych pylników o wydłużonej formie. Od chwili wytworzenia kwiatów męskich do chwili rozpoczęcia przez nie pylenia mija zwykle od 4 do 7 dni. Kwiaty męskie w pełni kwitnienia dają masę pyłku, którą wiatr może przenieść o kilka kilometrów, dlatego plantacje nasienne powinny być zakładane z zachowaniem należytej izolacji przestrzennej. Kwiaty żeńskie pozbawione są okwiatu i są wiatropylne. Jednozalążkowy słupek posiada dwa znamiona. Po około 4 tygodniach od zapylenia kwiaty żeńskie wytwarzają owoce zwane nasieniem.

\section{Nasiona}

Nasiona (owoce) konopi to orzeszki jednonasienne. Posiadają kształt kulisto - jajowaty, a z boku są lekko spłaszczone. Przeciętna masa 1000 nasion u konopi południowych wynosi $18-26 \mathrm{~g}$, u konopi pośrednich 12 - $18 \mathrm{~g}$, a u konopi dzikich 8 - 12 g. Nasiona osadzone są w kwiatostanie. Dojrzewają stopniowo, poczynając od dolnej części wiechy. Barwa nasion zmienia się $\mathrm{w}$ trakcie dojrzewania od zielonej do szarozielonej lub ciemnobrązowej. Nasiona konopi zawierają około 25\% białka, 35\% tłuszczu i $25 \%$ węglowodanów, co zobrazowano na rysunku 1 (Grabowska, Heller 2009). 

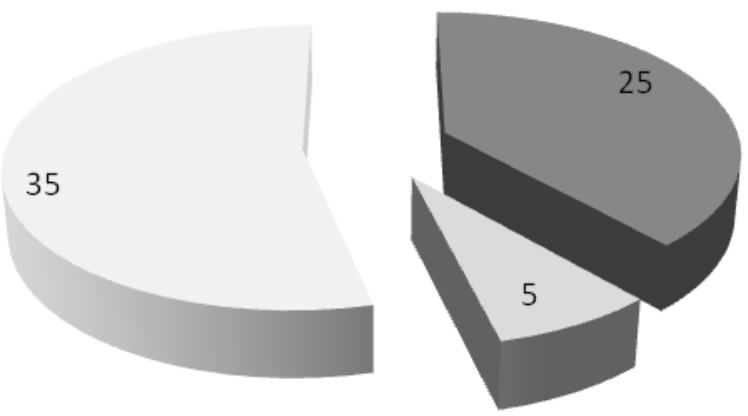

Białko \%

Węglowodany \%

Tłuszcze \%

Legend: Białko \% - Protein \%; Węglowodany \% - Carbohydrates \%; Tłuszcze \% - Fats \%

Figure 1. The nutritional content of the industrial hemp seeds (\%)

Rysunek 1. Zawartość składników pokarmowych w nasionach konopi włóknistych (\%)

\section{The history of cultivation and economic importance of industrial hemp}

France is the undisputed European leader in industrial hemp cultivation. Non-narcotic industrial hemp varieties are also widespread in Germany (Allin 2012 Bevan, Woolley 2010). Poland has a long tradition of industrial hemp cultivation. The cultivation range included areas of valuable natural assets, including the regions of Eastern Poland - Lublin region, Podlachia, and Greater Poland. The first research on farming, fibre production, technology of processing and utilisation of raw industrial hemp materials was carried out in the pre-war period. Native varieties of industrial hemp provided excellent quality fibre for fabrics, ropes and did not have narcotic properties. Due to the time-consuming and costly manufacturing process, industrial hemp was forced out of the market by rape, imported cotton, jute, sisal and plastic. Problems with sales and low profitability of industrial hemp production caused farmers to gradually abandon the cultivation of this plant. In subsequent years, the

\section{Historia uprawy i znaczenie gospodarcze konopi} włóknistych

Europejskim potentatem uprawy konopi jest Francja. Nienarkotyczne odmiany konopi są rozpowszechnione także w Niemczech (Allin 2012, Bevan, Woolley 2010) . Polska posiada wieloletnią tradycję uprawy konopi. Obszary uprawy obejmowały tereny o cennych walorach przyrodniczych, w tym rejony Polski Wschodniej - Lubelszczyznę i Podlasie, a także Wielkopolskę. Pierwsze badania dotyczące uprawy, produkcji włókna, technologii przerobu i zagospodarowania surowca prowadzone były w okresie przedwojennym. Rodzime odmiany konopi dawały znakomitej jakości włókno na płótno, liny i nie miały właściwości narkotycznych. Ze względu na czasochłonny i kosztowny proces przerobu konopie zostały wyparte z rynku przez rzepak, importowaną bawełnę, jutę, sizal i tworzywa sztuczne. Kłopoty ze zbytem oraz niska opłacalność produkcji konopi sprawiły, że rolnicy stopniowo zaczęli rezygnować $\mathrm{z}$ uprawy tej rośliny. W kolejnych latach prawie cał-

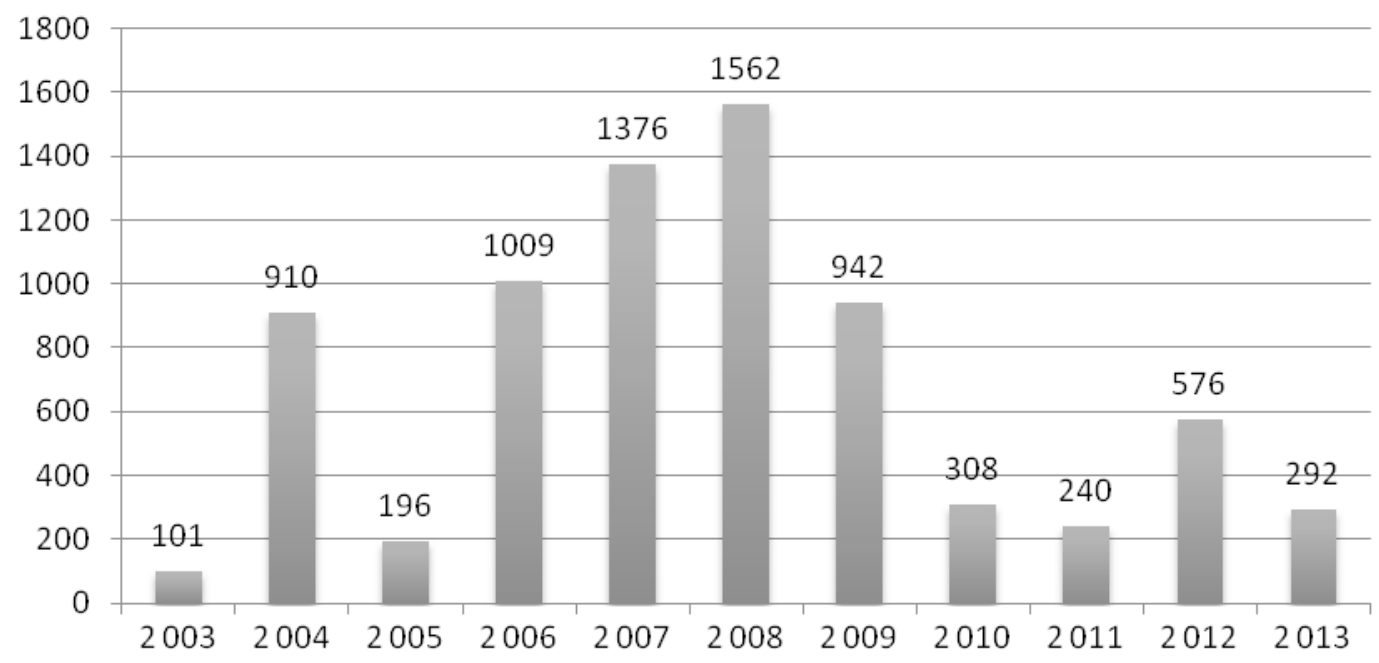

Figure 2. The area of industrial hemp cultivation (ha) in Poland in the years 2003-2013

Rysunek 2. Powierzchnia uprawy konopi włóknistych (ha) w Polsce w latach 2003-2013

Source: www.arimr.gov.pl

Źródło: www.arimr.gov.pl 
production of industrial hemp was almost entirely ceased. This plant was forgotten with the development of technology and the progress of civilization. The widespread use of the drug produced from the Indian varieties of cannabis - marijuana - contributed to the exclusion of industrial hemp farming. The downward trend in the cultivation of industrial hemp in the years 2003 - 2013 is shown in Figure 2.

Currently, the cultivation of industrial hemp is subject to strict legal limitations, which is determined by the Act of 24 April 1997 on counteracting drug addiction. The division of cannabis varieties into fibre crops and other ones, which can be used for intoxication purposes, was introduced. The strains in this species which contain less than $0.2 \%$ THC (tetrahydrocannabinol) in dry plant mass are considered to be fibre-yielding cannabis varieties (i.e. industrial hemp). The plants with higher THC content are considered as narcotic ones, and their cultivation, trade and possession are prohibited. The Act treats industrial hemp in the same way as poppy, i.e. a plant being subject to strict supervision, even if the cultivated varieties contain trace amounts of narcotic substances. Non-narcotic cannabis varieties are widespread in Germany, where they are used in the production of cosmetics and food products, as well as thermal insulation materials used in construction. The ban on the cultivation of highly narcotic cannabis varieties (e.g. the Indian one), has led to the search for new varieties of this plant. In the national register of the Research Centre for Cultivar Testing (henceforth referred to by its Polish abbreviation: COBORU) there are six cultivars of industrial hemp, developed in the Institute of Natural Fibres and Medicinal Plants in Poznań: Białobrzeskie, Beniko, Rajan, Tygra, Wojko and Wielkopolskie (www.coboru.pl). These are monoecious kowicie zaprzestano uprawy konopi, Rośliny te zostały zapomniane wraz rozwojem technologii oraz postępem cywilizacji. Do wykluczenia upraw konopi przyczyniło się rozpowszechnienie narkotyku, produkowanego z indyjskiej odmiany konopi - marihuany. Spadkową tendencję uprawy konopi włóknistych w Polsce w latach 2003 - 2013 obrazuje rysunek 2.

Obecnie uprawy konopi podlegają ostremu rygorowi prawnemu, który określa Ustawa z 24 kwietnia 1997 r. o przeciwdziałaniu narkomanii. Wprowadzono w niej podział konopi na włókniste i inne, mogące służyć celom odurzającym. Za konopie włókniste uważa się rośliny zawierające mniej niż 0,2\% THC (tetrahydrokannabinolu) w suchej masie ziela. Rośliny o większej zawartości THC uważane są za narkotyczne, a ich uprawa, obrót i posiadanie są zabronione. Ustawa traktuje konopie jak mak, czyli roślinę podlegającą ścisłemu nadzorowi, nawet jeśli uprawiane są odmiany o śladowych ilościach substancji narkotycznych. Nienarkotyczne odmiany konopi są rozpowszechnione w Niemczech, gdzie produkuje się z nich wiele produktów kosmetycznych i spożywczych, a także materiały termoizolacyjne, wykorzystywane w budownictwie. Zakaz uprawy wysoko narkotycznych odmian konopi (np. indyjskiej), przyczynił się do poszukiwania nowych odmian tej rośliny. W krajowym rejestrze Centralnego Ośrodka Badań Odmian Roślin Uprawnych (COBORU) znajduje się sześć odmian konopi, wyhodowanych w Instytucie Włókien Naturalnych i Roślin Zielarskich w Poznaniu: Białobrzeskie, Beniko, Rajan, Tygra, Wojko i Wielkopolskie (www.coboru.pl). Są to konopie jednopienne, typowo włókniste, zawierające mniej niż $0,2 \%$ substancji psychoaktywnych (THC), a jednocześnie charakteryzujące się wysoką wartością gospodarczą. Wraz

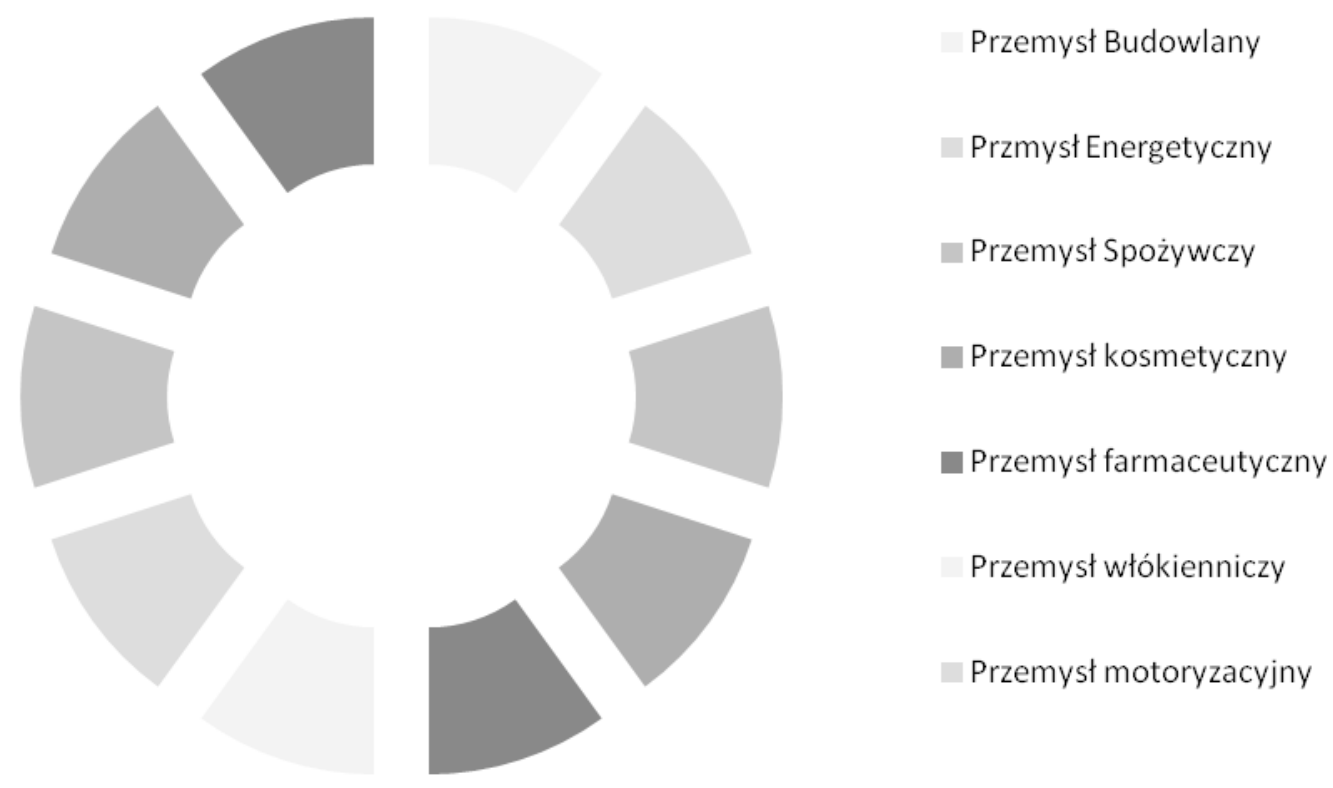

Legend: Przemysł Budowlany - Construction industry; Przemysł Energetyczny - Power industry; Przemysł Spożywczy - Food industry; Przemysł kosmetyczny - Cosmetic industry; Przemysł farmaceutyczny - Pharmaceutical industry; Przemysł włókienniczy - Textile industry; Przemysł motoryzacyjny - Automotive industry

Figure 3. The possibility of using fibre-yielding industrial hemp cultivars in industry Rysunek 3. Możliwość wykorzystania konopi włóknistych w przemyśle 
industrial hemp varieties, typical fibre crops, containing less than $0.2 \%$ of psychoactive substances (THC), at the same time being characterised by high economic value. With increasing environmental awareness and the search for alternative sources of raw materials in the 90s of the last century in Europe and worldwide, industrial hemp was discovered again as an attractive plant for agriculture and many industries. This is evidenced by multiple possibilities of using this plant in many industries, shown in Figure 3.

\section{Climate and soil requirements}

The industrial hemp cultivars registered in the Research Centre for Cultivar Testing (COBORU), have a period of vegetation adapted to temperate climate. They can be grown in the area of Eastern Poland, which are classified as areas of high nature value. Polish monoecious cultivars belong to the Central - European forms. They are adapted to the conditions of temperate climate, and when necessary development requirements are ensured, they can be grown throughout the country (Jaranowska 1962). Ensuring optimum climatic and soil conditions along with the use of proper agricultural technology guarantees a high yield, with specific technological parameters of seeds, straw and fibre. During the vegetation period industrial hemp requires 200 $300 \mathrm{~mm}$ of rainfall. In the cultivation of industrial hemp, the amount of water in the soil has much greater significance than a large amount of precipitation (Grabowska, Koziara 2001). For the proper development of industrial hemp, it is not only the total sum of rainfall which matters, but also the distribution of precipitation during the vegetation season. Water consumption is correlated with the intensity of plant growth - the greatest consumption occurs when the plant "shoots into the stem". In Polish climate conditions, the amount of rainfall allows industrial hemp plants to achieve proper development. Their root system, if not prevented by the groundwater level or the type of substrate, reaches to the depth which allows for collecting water from deeper layers of the soil and surviving periods of drought. Despite the high demand for water industrial hemp does not tolerate high levels of ground water, which in mineral soils should not be higher than $80 \mathrm{~cm}$. Excessive humidity, exceeding $80 \%$ of field capacity, hinders the development of the root system and adversely affects the growth of these plants. Hemp belongs to thermophilic plants. The heat demand of industrial hemp is relatively high. In the geographical zone between $51^{\circ}$ and $58^{\circ}$, the sum of growing degree days during the vegetation period of industrial hemp is $2000-2600^{\circ} \mathrm{C}$. The heat demand in the period from germination to technical ripening is $1900-2000^{\circ} \mathrm{C}$ and $2700-3000^{\circ} \mathrm{C}$ to biological ripening. Sufficient heat during the most intensive development period of industrial hemp, i.e., in June and July, is very important for their proper growth. Observations to date have shown that low temperatures and the lack of rainfall in this period tend to hinder their growth and negatively ze wzrastającą świadomością ekologiczną i poszukiwaniem alternatywnych źródeł surowców w latach 90 - tych ubiegłego wieku w Europie i na świecie odkryto konopie ponownie jako roślinę atrakcyjną dla rolnictwa i wielu gałęzi przemysłu. Świadczą o tym bardzo szerokie możliwości wykorzystania tej rośliny $\mathrm{w}$ wielu gałęziach przemysłu, przedstawione na rysunku 3.

\section{Wymagania klimatyczno glebowe}

Odmiany konopi włóknistych, zrejestrowane w Krajowym Rejestrze Centralnego Ośrodka Badań Odmian Roślin Uprawnych (COBORU) mają okres wegetacji dostosowany do warunków klimatu umiarkowanego. Mogą być uprawiane na terenach Polski Wschodniej, które zaliczane są do obszarów przyrodniczo cennych. Polskie odmiany konopi jednopiennych, należą do form środkowo - europejskich. Przystosowane są do warunków klimatu umiarkowanego i po zapewnieniu niezbędnych do ich prawidłowego rozwoju wymagań mogą być uprawiane w całym kraju (Jaranowska 1962). Zapewnienie optymalnych warunków klimatyczno glebowych i zastosowanie właściwej agrotechniki gwarantuje uzyskanie wysokiego plonu, o określonych parametrach technologicznych nasion, słomy i włókna. W okresie wegetacji konopie wymagają $200-300$ mm opadów. W uprawie konopi znacznie większą rolę odgrywa dostateczna ilość wody w glebie niż duża ilość opadów atmosferycznych (Grabowska, Koziara 2001). Dla prawidłowego rozwoju konopi istotna jest nie tylko ogólna suma, ale również rozkład opadów w okresie wegetacji. Zużycie wody skorelowane jest $\mathrm{z}$ intensywnością wzrostu roślin - największe zużycie występuje w okresie „strzelania rośliny w łodygę". W warunkach klimatycznych Polski suma opadów wystarcza roślinom konopi do prawidłowego rozwoju. Ich system korzeniowy, o ile nie przeszkodzi mu poziom wody gruntownej lub rodzaj podłoża sięga głęboko, co pozawala na pobieranie wody z głębszych warstw gleby i przetrwanie okresów suszy. Mimo dużego zapotrzebowania na wodę konopie źle znoszą wysoki poziom wód gruntowych, który na glebach mineralnych nie powinien być wyższy niż $80 \mathrm{~cm}$. Nadmierna wilgotność przekraczająca $80 \%$ polowej pojemności wodnej gleby hamuje rozwój systemu korzeniowego i niekorzystnie wpływa na wzrost roślin. Konopie należą do roślin ciepłolubnych. Zapotrzebowanie cieplne konopi jest stosunkowo wysokie. W strefie geograficznej pomiędzy $51^{\circ}$ i $58^{\circ}$ suma ciepła $\mathrm{w}$ okresie wegetacji konopi wynosi $2000-2600^{\circ} \mathrm{C}$. Zapotrzebowanie cieplne w okresie od wschodów do dojrzałości technicznej konopi wynosi $1900-2000^{\circ} \mathrm{C}$, a do dojrzałości biologicznej 2700 - 3000ํㅡ. Dla prawidłowego rozwoju konopi bardzo ważna jest wystarczająca ilość ciepła w okresie ich najintensywniejszego rozwoju tj. w czerwcu i lipcu. Dotychczasowe obserwacje dowodzą, że niska temperatura i brak opadów w tym okresie wpływają hamująco na wzrost i od- 
impact the yield of straw, fibre and seeds, while the optimum temperature during these months allows industrial hemp to achieve daily growth in excess of $10-12 \mathrm{~cm}$. The seeds germinate at a temperature of $8-10^{\circ} \mathrm{C}$ for $8-12$ days. Young plants tolerate frosts to $-6^{\circ} \mathrm{C}$, which allows for relatively early sowing of industrial hemp, thus allowing it to achieve biological ripening no later than in mid-September (Bocsa and Karus 1997). In the climate conditions of Poland, it is a crucial to additionally dry straw and seeds. Temperature and precipitation interact with each other and the plants are able to compensate for the effect of adverse weather conditions prevailing in one of the development phases. An important element of agricultural technology is the sowing time. The development of industrial hemp largely depends on the amount of sunlight, particularly on the length of the day (long-day conditions increase the vegetative growth phase). Hemp is an intensively growing plant. It produces a huge amount of green mass very quickly. One of the basic conditions for achieving a good yield is the choice of appropriate soil. Cannabis is considered to be a plant of river valleys and lowlands. The most appropriate soil types for it are fertile ones, rich in humus, nitrogen and calcium, with neutral or slightly alkaline $\mathrm{pH}$ (Dempsey 1975, Jaranowska 1962). Light, sandy and heavy, loamy soils, as well as continuously waterlogged areas, should be avoided. Freshly tilled fields offer excellent sites where industrial hemp finds good conditions for growth and additionally clears weeds off them. The analysis of Polish climate and soil conditions and the requirements for cannabis in this respect, performed at the Institute of Natural Fibres and Medicinal Plants in Poznań, showed that the cultivation of this plant is possible in almost the entire country, including, to a considerable extent, areas of high nature value.

\section{Agrotechnical requirements}

\section{Position in crop rotation}

Hemp is distinguished by its very good selftoleration,i.e.with propersoilfertilityandappropriate fertilization it can be grown in monocultures, i.e. several times in the same position without reduction of yield. It must be borne in mind, however, that such conditions are then conducive to the spread of fungal diseases and intensification of the flea beetle infestation. While determining the proper position in crop rotation, the following characteristics of industrial hemp should be taken into account:

- the introduction of industrial hemp crop rotation can be considered as a weeding treatment,

- they choke weeds by producing large quantities of biomass,

- as a result of the decomposition of a deep and well-developed root system they ensure good ventilation of the soil and humus supply,

- by shading and covering the soil, industrial hemp leaves it well-structured, thus being a perfect forecrop for cereal crops (for winter wheat it contributes to a harvest increase of about $20 \%$ ). bijają się niekorzystnie na wysokości plonów słomy, włókna i nasion, natomiast optymalna temperatura $w$ tych miesiącach umożliwia dzienne przyrosty konopi przekraczające 10 - $12 \mathrm{~cm}$. Nasiona kiełkuja przy temperaturze 8 - $10^{\circ} \mathrm{C}$ w ciągu 8 - 12 dni. Młode rośliny znoszą przymrozki do - 6ํㅡ, co umożliwia stosunkowo wczesny siew konopi, pozwalający na osiągnięcie dojrzałości biologicznej nie później niż w połowie września (Bocsa i Karus 1997). W warunkach klimatycznych Polski ma to istotne znaczenie wobec konieczności dosuszenia słomy i nasion. Temperatura i opady współdziałają ze sobą, a rośliny są zdolne zrekompensować sobie efekt niekorzystnych warunków pogodowych panujących w jednej $\mathrm{z}$ faz rozwojowych. Istotnym elementem agrotechniki jest termin siewu. Rozwój konopi w dużej mierze zależy od ilości światła, a szczególnie od długości dnia (w warunkach dnia długiego wydłuża się faza wzrostu wegetatywnego). Konopie są rośliną o intensywnym wzroście. Bardzo szybko wytwarzają ogromną ilość zielonej masy. Jednym z podstawowych warunków uzyskania dobrego plonu jest wybór właściwej gleby. Konopie uważane są za rośliny dolin rzecznych i nizin. Najodpowiedniejsze są dla nich gleby żyzne, bogate w próchnicę, azot i wapń, o odczynie obojętnym lub lekko zasadowym (Dempsey 1975, Jaranowska 1962). Powinno się unikać gleb lekkich, piaszczystych i ciężkich ilastych, jak również terenów stale podmokłych. Doskonałym stanowiskiem są nowiny, na których konopie znajdują dobre warunki rozwoju i dodatkowo oczyszczają je z chwastów Wykonana w Instytucie Włókien Naturalnych i Roślin Zielarskich w Poznaniu analiza warunków klimatyczno - glebowych Polski i wymagań konopi w tym zakresie wykazała, że uprawa tej rośliny jest możliwa niemal w całym kraju, a w tym w znacznej mierze na obszarach o cennych walorach przyrodniczych.

\section{Wymagania agrotechniczne}

\section{Stanowisko w płodozmianie}

Konopie wyróżniają się bardzo dobrą samotolerancją tzn. przy odpowiedniej żyzności gleby i odpowiednim nawożeniu można je uprawiać w monokulturze, tj. wielokrotnie na tym samym stanowisku bez strat plonu. Należy jednak pamiętać, że wówczas sprzyjają warunki do szerzenia się chorób grzybowych i nasilenia pchełki ziemnej. Przy wyznaczaniu właściwego stanowiska w zmianowaniu należy uwzględnić następujące cechy konopi:

- wprowadzenie konopi do zmianowania można traktować jako zabieg odchwaszczający,

- wytwarzając duże ilości biomasy zagłuszają chwasty,

- w wyniku rozkładu głębokiego i rozwiniętego systemu korzeniowego zapewniają dobre przewietrzenie gleby i zaopatrzenie w próchnicę,

- ocieniając i osłaniając glebę pozostawiają ją w dobrej strukturze, są więc doskonałym przedplonem dla zbóż (w przypadku pszenicy ozimej powodują. zwyżkę plonu o około $20 \%$ ). 


\section{Fertilization}

Hemp is characterized by a rapid growth of biomass. It requires not only fertile soils, but also proper fertilization. The weaker the site, the stronger should be its fertilisation. The recommended doses of pure agents are:

$$
\begin{aligned}
& -90-120 \mathrm{~kg} / \mathrm{ha} \mathrm{N}, \\
& -70-100 \mathrm{~kg} / \mathrm{ha} \mathrm{P}_{2} \mathrm{O}_{5} \\
& -150-180 \mathrm{~kg} / \mathrm{ha} \mathrm{K}_{2} \mathrm{O} \\
& \text { - on acidic soils } 15-20 \mathrm{q} / \mathrm{ha} \mathrm{CaO} \text {. }
\end{aligned}
$$

Specific nutrients differently affect the quality and the quantity of the harvest: nitrogen affects the growth of plants, potassium is used for the formation of fibres and phosphorus is actively involved in seed formation. As in the case of the formation of the biomass in other plants, nitrogen plays a decisive role in determining the amount of straw and fibre harvest. Excessive nitrogen dosage extends the vegetation period of industrial hemp, promotes the exuberance of plants and reduces the content and quality of fibre in stems.

\section{Sowing date}

An appropriate sowing date is largely determined by the course of weather conditions in the spring and is of crucial significance in cultivating industrial hemp. In southern Poland, the optimum sowing time for industrial hemp falls in the first and second decade of April, in central Poland in the second and third decade of April, in northern Poland it is extended to mid-May. Sowing industrial hemp in cold soil causes excessively long seed germination and higher percentage of germination atrophy. In contrast, excessively delayed sowing shortens the period of vegetation to a large extent, thus reducing the crop yield and its quality. Hemp sown very late, i.e. at the beginning of July, ripens only slightly later than the one sown in early April. However, it yields a much lower harvest of straw, especially fibre and seed.

\section{The density of sowing and row spacing}

Only certified seeds are planted. The optimum sowing density for industrial hemp depends primarily on the purpose of the harvest and conditions of climate and soil. The number of plants per unit of area is essential for the output and quality of the fibre. In seed plantations, it is recommended to sow $10-15 \mathrm{~kg} /$ ha and apply row spacing of $50 \mathrm{~cm}$. Row spacing of $7.5-15 \mathrm{~cm}$ is applied in industrial plantations and the amount of sown seed depends on the cultivation type and ranges from 40 to $70 \mathrm{~kg} / \mathrm{ha}$ :

- 30 - $40 \mathrm{~kg} / \mathrm{ha}$ - biocomposites,

- $60-70 \mathrm{~kg} / \mathrm{ha}$ - cellulose (textile purposes).

\section{Treatments}

Due to the strong growth of industrial hemp and its competitiveness against weeds, field treatment may prove to be redundant, especially in fibre-oriented cultivation. However, if a given field has been weakly cultured, it is recommended to use Afalon before shoot emergence at a dose of $1-1.2 \mathrm{~kg} / \mathrm{ha}$.

\section{Nawożenie}

Konopie wyróżniają się szybkim przyrostem biomasy. Potrzebują, nie tylko żyznych gleb, ale również odpowiedniego nawożenia. Im stanowisko jest słabsze, tym silniej powinno być nawożone. Zalecane w czystym składniku dawki to:

$-90-120 \mathrm{~kg} / \mathrm{ha} \mathrm{N}$,

- 70 - $100 \mathrm{~kg} / \mathrm{ha} \mathrm{P}_{2} \mathrm{O}_{5}$

- 150 - $180 \mathrm{~kg} / \mathrm{ha} \mathrm{K}{ }_{2} \mathrm{O}$

- na glebach zakwaszonych 15 - 20 q/ha CaO.

Poszczególne składniki pokarmowe wpływają różnie na jakość i ilość uzyskanego plonu: azot wpływa na wzrost rośliny, potas wykorzystany jest przy tworzeniu się włókna, a fosfor bierze czynny udział w wykształceniu nasion. Podobnie jak w przypadku tworzenia się biomasy innych roślin, decydującą rolę w kształtowaniu się wysokości plonu słomy i włókna odgrywa azot. Nadmierna dawka azotu przedłuża okres wegetacji konopi, sprzyja wybujałości roślin i obniża zawartość oraz jakość włókna w łodygach.

\section{Termin siewu}

Właściwy termin siewu w znacznym stopniu wyznaczany jest przez przebieg warunków atmosferycznych wiosną i ma zasadnicze znaczenie przy uprawie konopi. W Polsce południowej optymalny termin siewu konopi przypada w I i II dekadzie kwietnia, w Polsce środkowej w II i III dekadzie kwietnia, a w Polsce północnej wydłuża się do połowy maja. Wysiew konopi w zimną glebę powoduje zbyt długie kiełkowanie nasion i wzrost procentu zaników roślin. Natomiast nadmierne opóźnienie siewu skraca gwałtowne okres wegetacji obniżając wysokość i jakość plonu. Konopie zasiane bardzo późno tj. na początku lipca, dojrzewają niewiele później niż zasiane na początku kwietnia, jednak dają znacznie niższe plony słomy, zwłaszcza włókna i nasion.

\section{Gęstość siewu i rozstawa rzędów}

Sieje się tylko kwalifikowany materiał siewny. Optymalna gęstość siewu konopi zależy przede wszystkim od przeznaczenia plonu i warunków klimatyczno - glebowych. Liczba roślin na jednostce powierzchni ma podstawowe znaczenie dla wydajności i jakości włókna. Na plantacjach nasiennych zaleca się wysiew 10-15 kg/ha i rozstawę rzędów $50 \mathrm{~cm}$. Na plantacjach przemysłowych stosuje sie rozstawę rzędów 7,5 - $15 \mathrm{~cm}$, a ilość wysiewu zależy od celu uprawy i wynosi od 40 do $70 \mathrm{~kg} / \mathrm{ha}$ :

- 30 - $40 \mathrm{~kg} / \mathrm{ha}$ - biokompozyty,

- 60 - $70 \mathrm{~kg} / \mathrm{ha}$ - celuloza (cele włókiennicze).

\section{Zabiegi pielęgnacyjne}

Z uwagi na silny wzrost konopi i konkurencyjność w stosunku do chwastów, zabiegi pielęgnacyjne mogą okazać się zbyteczne, zwłaszcza w uprawie na włókno. Jeśli jednak pole pozostaje w słabej kulturze, to zaleca się stosowanie przed wschodami Afalonu w dawce $1-1,2 \mathrm{~kg} / \mathrm{ha}$. 


\section{Pests and diseases}

Hemp requires the application of pesticides to a very small degree or not at all. However, with the propagation of its cultivation and concentration of industrial hemp plantations one must take into consideration the possibility of pests (e.g. hop flea beetles and corn borers) and diseases (e.g. seedling blight, grey mould, Sclerotinia sclerotiorum).

\section{Harvest date}

The date of industrial hemp harvest is one of the most important factors determining the size and quality of the harvest output. It depends primarily on the dynamics of climatic conditions during the growing season, crop varieties and farming directions - it takes place in the following months: August September. When the seeds ripen in the central part of the panicle - at their full maturity - seed plantations are harvested - a delay in gathering the harvest causes seed shedding and losses resulting from the foraging activity of birds, occurrence of diseases and decreasing seed quality. A high yield of fibre and seeds of a slightly worse quality, which constitute industrial material (e.g. for the production of oil or bird and fish feed), is obtained from industrial plantations within this period. Harvest within 1 - 2 weeks after blooming termination allows one to obtain a high yield of strong fibres, while gathering the crop about 2 weeks earlier allows one to obtain delicate fibre for yarn spinning (Grabowska, Heller 2009).

\section{Perspectives of industrial hemp cultivation in areas of high nature value}

Areas of natural value can be viewed in two ways. On the one hand, they pose a barrier to introducing new investments and intensive production. However, the goal is not to cease economic activity, and thus delay the development of a region, but to structure it in such a way that allows for preserving the biodiversity occurring in the area. On the other hand, these areas can act as a driving force for local development, owing to the use of their recreational, cultural and tourist value. Increasingly, due to the fact that biodiversity is being perceived as a broad concept, they are linked with the necessity of special protection of their historical and landscape values (Lipińska 2013). Integrated economic management in areas of high nature value, consistent with the concept of sustainable development is a very important issue, but at the same time it is a complex one, requiring further research. It becomes particularly significant when we consider civilizational threats, climate change or loss of biodiversity (Zielińska 2013). Traditional nature conservation, in which the emphasis is placed on the protection of individual ecological components, as distinct forms in the landscape, loses its importance. Currently, it is desirable not only to protect the ecosystems, since they are by definition unstable and undergo a continuous process of evolution, but also preserving the processes that shape them: the flow of matter, energy and information within and between the systems, as well as the stabilization of

\section{Szkodniki i choroby}

Konopie tylko w niewielkim stopniu, albo w ogóle nie wymagają stosowania środków ochrony roślin. Jednak wraz z rozpowszechnieniem uprawy i koncentracją plantacji konopi należy liczyć się z możliwością wystąpienia szkodników (np. pchełki chmielowej i omacnicy prosowianki) oraz chorób (np. zgorzel siewek, szara pleśń, zgnilizna twardzikowa).

\section{Termin zbioru}

Termin zbioru konopi należy do najważniejszych czynników warunkujących wielkość i jakość plonu. Zależy on przede wszystkim od przebiegu warunków klimatycznych w okresie wegetacji, odmiany i kierunków uprawy - odbywa się w miesiącach: sierpień - wrzesień. W pełnej dojrzałości gdy dojrzewają nasiona w środkowej części wiechy zbieramy plantacje nasienne - opóźnienie sprzętu powoduje osypanie się nasion i straty wynikłe z żerowania ptaków, występowania chorób i obniżenia klasy materiału siewnego. Na plantacjach przemysłowych w tym terminie uzyskujemy wysoki plon włókna i nieco gorszej jakości nasiona, które są materiałem przemysłowym (np. na olej lub pokarm dla ptaków, czy ryb). Zbiór 1 - 2 tygodnie po okwitnięciu pozwala na uzyskanie wysokiego plonu mocnego włókna, natomiast zbierając około 2 tygodnie wcześniej uzyskujemy delikatne włókno przędzalnicze (Grabowska, Heller 2009).

\section{Perspektywy uprawy konopi włóknistych na obszarach przyrodniczo cennych}

Obszary przyrodniczo cenne można postrzegać w dwojaki sposób. Z jednej strony stanowią one barierę dla wprowadzania nowych inwestycji i intensywnej produkcji. Jednakże ich celem nie jest zaprzestanie prowadzenia działalności gospodarczej, a tym samym wstrzymanie rozwoju danego regionu, lecz takie jej ukształtowanie, aby można było zachować występującą na danym obszarze bioróżnorodność. $\mathrm{Z}$ drugiej strony obszary te mogą być stymulatorami rozwoju lokalnego przez wykorzystanie ich walorów wypoczynkowych, kulturowych i turystycznych. Coraz częściej, z uwagi na szerokie pojęcie różnorodności biologicznej, łączy się je z koniecznością szczególnej ochrony ich wartości historycznych i krajobrazowych (Lipińska 2013). Zintegrowane gospodarowanie na obszarach przyrodniczo cennych, zgodne z koncepcją rozwoju zrównoważonego jest zagadnieniem bardzo ważnym, ale jednocześnie złożonym i wymagającym dalszych badań. Nabiera ono szczególnego znaczenia wobec zagrożeń cywilizacyjnych, zmian klimatu czy utraty bioróżnorodności (Zielińska 2013). Tradycyjna ochrona przyrody, w której nacisk położony jest na ochronę poszczególnych elementów ekologicznych, jako odrębnych form w krajobrazie, traci na znaczeniu. Obecnie pożądana jest ochrona nie tylko samych ekosystemów, ponieważ są one z założenia niestabilne i ulegają ciągłej ewolucji, ale zachowanie procesów je kształtujących: przepływu materii, energii i informacji, wewnątrz 
external factors impacting ecosystems. Preserving a relatively unchanged pressure of external factors on an ecosystem ensures the capacity of ecological systems to adapt to it. The cause of the devastation of ecosystems is not so much the existence of anthropogenic factors as their intensity and rate of change. The driving force behind the development of ecosystems is evolution, i.e. a very efficient but slow process. Adaptation however cannot occur without the possibility of the free flow of matter, energy and information within and between ecosystems (Poskrobko 2011). It is very important to present a new approach to farming in areas of high nature value. It should rely on the use of the potential inherent in these areas, but also on the potential of selected plant species in accordance with sustainable development. Due to the specific biological properties, growing requirements and various utilization directions, industrial hemp is among the crops of major importance for implementing the idea of sustainable development of agriculture. It produces a large amount of green biomass, which shades for the soil during the growing season, and its welldeveloped root system decomposes after harvesting. Hemp root system improves soil structure through appropriate ventilation and accumulation of humus. Hemp is a good forecrop for other crops; it does not require the use of pesticides. Moreover, it is resistant to diseases and pests, and used materials made from industrial hemp can be processed through recycling with low labour intensiveness. Hemp foliage can be used as fodder. By absorbing $\mathrm{CO}_{2}$, industrial hemp plants contribute to reducing the greenhouse effect ( 1 ha of industrial hemp absorbs about $2.5 \mathrm{t}$ of $\mathrm{CO}_{2}$ ), and in the process of burning biomass they emit less $\mathrm{CO}_{2}$ and $\mathrm{CO}$ than mineral fuels. Hemp can be grown in contaminated areas where, by absorbing heavy metals such as cadmium, lead, zinc and copper, it contributes to their rehabilitation. In 2012 the Institute of Natural Fibres and Medicinal Plants in Poznań implemented a project aimed at the rehabilitation of degraded soils in mine reclamation areas by sowing industrial hemp.

Due to low cultivation requirements, industrial hemp farming should be of interest to farmers. The climate occurring in Poland (except for mountain ranges) qualifies it as an ideal place for growing industrial hemp. Suitable land for industrial hemp cultivation can be found in every region of Poland. The only problem posed by the climate may be the shortage of water at the early stage of cultivation (from shoot emergence until the end of flowering). Selecting an appropriate cultivation area constitutes an important factor - areas retaining water and characterised by appropriate sun exposure are considered the best. Because of the well-developed root system, sufficient amount of water in the soil plays a greater role in industrial hemp cultivation than a large amount of precipitation. Hemp can be grown on mineral and peat soils. The best soil types are deep soils, rich in humus and lime which do not undergo sealing and remain airy but with good water retention. Hemp can be grown on medium quality soils as long as there is good fertilization oraz między systemami, a także ustabilizowanie wpływu czynników zewnętrznych na ekosystemy. Zachowanie względnie niezmiennej presji czynników zewnętrznych na ekosystem gwarantuje możliwość dostosowania się do niej układów ekologicznych. Przyczyną dewastacji ekosystemów jest nie tyle fakt istnienia czynników antropogenicznych, ile ich natężenie i szybkość zmiany. Motorem napędzającym rozwój ekosystemów jest ewolucja, czyli proces bardzo skuteczny, ale powolny. Zmiany dostosowawcze nie mogą jednak zachodzić bez możliwości swobodnego przepływu materii, energii i informacji wewnątrz i między ekosystemami (Poskrobko 2011). Bardzo ważne jest ukazanie nowego podejścia do gospodarowania na obszarach przyrodniczo cennych. Powinno ono polegać na wykorzystaniu potencjału tkwiącego w tych obszarach, ale również potencjału dobieranych gatunkach roślin zgodnie z rozwojem zrównoważonym. Konopie dzięki specyficznym właściwościom biologicznym, wymaganiom uprawowym i różnym kierunkom uży tkowania zaliczane są do upraw o dużym znaczeniu $\mathrm{w}$ realizacji idei zrównoważonego rozwoju rolnictwa. Wytwarzają ogromną ilość zielonej biomasy, która ocienia glebę podczas wegetacji, a dobrze rozwinięty system korzeniowy po zbiorze roślin ulega rozkładowi. System korzeniowy konopi poprawia strukturę gleby poprzez odpowiednie przewietrzenie i nagromadzenie próchnicy. Konopie są dobrym przedplonem dla innych roślin uprawnych, nie wymagają stosowania środków ochrony roślin, są odporne na choroby i szkodniki, a zużyty materiał wykonany z konopi przy niskich nakładach nadaje się do przetworzenia $\mathrm{w}$ drodze recyklingu. Liście konopi mogą być wykorzystywane do celów pastewnych. Rośliny konopi poprzez wiązanie $\mathrm{CO}_{2}$ przyczyniają się do ograniczenia efektu cieplarnianego (1ha konopi wiąże około $2,5 \mathrm{t} \mathrm{CO}_{2}$ ), a podczas spalania biomasy emitują do atmosfery mniej $\mathrm{CO}_{2}$ i $\mathrm{CO}$ niż surowce kopalniane. Konopie można uprawiać na terenach skażonych, gdzie absorbując metale ciężkie, takie jak kadm, ołów, cynk, miedź przyczyniają się do ich rekultywacji. W 2012 r. Instytut Włókien Naturalnych i Roślin Zielarskich w Poznaniu wdrożył projekt mający na celu rekultywację zdegradowanych gleb na terenach pokopalnianych, poprzez obsiew konopi włóknistej.

Uprawa konopi powinna zainteresować rolników ze względu na niskie wymagania uprawowe. Klimat występujący w Polsce predestynuje nasz kraj (poza pasmami górskimi) jako idealne miejsce do uprawy konopi. W każdym rejonie można znaleźć odpowiednie tereny pod uprawę. Jedyny problem klimatyczny we wczesnej fazie uprawy (od wschodów do końca kwitnienia) może stanowić niedobór wody. Ważnym elementem jest dobór odpowiedniego stanowiska uprawy - najlepsze są tereny zatrzymujące wodę w glebie i pozostające w odpowiednim nasłonecznieniu. Ze względu na rozwinięty system korzeniowy w uprawie konopi większą rolę odgrywa dostateczna ilość wody w glebie niż duża ilość opadów atmosferycznych. Konopie można uprawiać na glebach mineralnych i torfowych. Najlepsze są gleby głębokie, bogate w próchnicę i wapno, niezaskorupiające się, 
and low weed infestation. The following types of soil are not suitable for industrial hemp cultivation: heavy, loamy soils, as well as ones undergoing soil sealing and exhibiting impermeability, in addition to overly dry sandy and clay soils with poor structure. From the cultivation point of view, an important feature of industrial hemp is its good utilisation of the soil fertilizing capacity and the lack of specific requirements related to the forecrop. It can be sown in succession to any plant. Good forecrops include plants of the Fabaceae family (alfalfa, clover, peas, vetch, field pea) and root crops. There are no contraindications for long-term cultivation of industrial hemp in a continuous cropping system (but not longer than 3 years). To conclude, industrial hemp, due to its specific biological properties, low cultivation and agrotechnical requirements and lack of the necessity to use pesticides, can be successfully grown in areas of high nature value while preserving their specific character and biodiversity. przewiewne, ale dobrze zatrzymujące wode. Można je uprawiać na glebach średnich pod warunkiem dobrego nawożenia i niskiego zachwaszczenia. Pod uprawę konopi nie nadają się gleby ciężkie, ilaste, łatwo zaskorupiające się i nieprzepuszczalne, a także zbyt suche gleby piaszczysto - gliniaste, nie znajdujące się w wysokiej kulturze. Istotną cechą konopi z punktu widzenia jej uprawy jest dobre wykorzystanie siły nawozowej gleby oraz brak szczególnych wymagań co do przedplonu. Można je siać po każdej roślinie. Do dobrych przedplonów zalicza się rośliny z rodziny motylkowych (lucerna, koniczyna, groch, wyka, peluszka) oraz okopowe. Nie istnieja przeciwwskazania do wieloletniej uprawy konopi w systemie ciągłym (nie dłużej jednak niż 3 lata). Podsumowując należy stwierdzić, że konopie włókniste ze względu na specyficzne właściwości biologiczne, niskie wymagania uprawowe i agrotechniczne oraz brak konieczności stosowania pestycydów z powodzeniem mogą być uprawiane na obszarach cennych przyrodniczo zachowując ich specyfikę i bioróżnorodność.

\section{References/ Literatura:}

1. Allin S. (2012), Building with hemp. Seed Press, Ireland.

2. Andersen E., Baldock D., Bennett H. (2003), Developing a high nature value indicator. Report for the European Environment Agency, Copenhagen. eea.eionet.europa.eu (data dostępu: 17.02.2013).

3. Bevan R., Woolley T. (2010), HempLime Construction: A Guide to Building with Hemp Lime Composites. BRE Press, Bracknell.

4. Bocsa I., Karus M. (1997), Der Hanfanbau. C.F. Muller, Heidelberg.

5. Cieszewska A. (2008), Zachowanie terenów cennych przyrodniczo w kształtowaniu struktury krajobrazu na poziomie miejscowego planu zagospodarowania przestrzennego. Problemy Ekologii Krajobrazu, T. XXI, s. 239-250.

6. Dempsey J.M. (19750, Fiber crops. Hemp. University of Florida, Gainesville.

7. Grabowska L., Heller K. (2009), Materiały szkoleniowe nt. „Uprawa Inu i konopi w ekologicznych gospodarstwach agroturystycznych". Wyd. Sulin, Białystok.

8. Grabowska L., Koziara W. (2001), Wpływ temperatury i opadów na plonowanie konopi włóknistych odm. Białobrzeskie. Natural Fibres Vol. XXXXV, Poznań.

9. Hajduk S. (2011), Obszary prawnej ochrony przyrody a prace planistyczne w gminach województwa podlaskiego, W: Zrównoważony rozwój obszarów przyrodniczo cennych. Planistyczne i implementacyjne aspekty rozwoju obszarów przyrodniczo cennych. Wyd. WSE, Białystok, T. I, s. 32-50.

10. Idole E., Bines T. (2004), Planowanie ochrony obszarów cennych przyrodniczo - przewodnik dla praktyków i ich szefów. Wyd. Polski Klub Przyrodników, Świebodzin.

11. Jalinik M. (2002), Zarzq̨dzanie gospodarstwem ekoagroturystycznym na obszarach przyrodniczo cennych. Zesz. Nauk. Politechniki Białostockiej, Ekonomia i Zarządzanie, nr 14, s. 87-88.

12. Jaranowska B. (1962), Konopie jednopienne. Wyd. PWRiL, Warszawa.

13. Kistowski M. (2007), Kolizje i konflikty środowiskowe w planowaniu przestrzennym na obszarach cennych przyrodniczo. Czasopismo Techniczne, z. 7 - A, s. 249-255.

14. Lipińska I. (2013), Rozwój obszarów przyrodniczo cennych - aspekty społeczne, ekonomiczne i prawne. Roczniki Naukowe Stowarzyszenia Ekonomistów Rolnictwa i Agrobiznesu, XV, Z. 1, s. 121-126.

15. Łuszczyk M. (2011), Kierunki rozwoju społeczno-gospodarczego obszarów przyrodniczo cennych, W: T. Poskrobko (red.), Zrównoważony rozwój obszarów przyrodniczo cennych. Wyd. WSE, Białystok, T.I, s. 260-276.

16. Piontek F. (2002), Sektorowość i integralność kapitału ludzkiego i przyrodniczego w procesie globalizacji, W: F. Piontek (red.), Kapitał ludzki w procesie globalizacji a w zrównoważonym rozwoju. Wyd. ATH w Bielsku Białej, s. 155-169..

17. Poskrobko T. (2011), Planistyczne i implementacyjne aspekty rozwoju obszarów przyrodniczo cennych, W: T. Poskrobko (red.), Zrównoważony rozwój obszarów przyrodniczo cennych. Wyd. WSE, Białystok, s. 1-328.

18. Steiner F. (1999), The living landscape. An Ecological Approach to Landscape Planning. McGraw Hill.

19. Ustawa o przeciwdziałaniu narkomanii z dnia 24 kwietnia 1997 r. (Dz.U. 1997 nr 75 poz. 468).

20. Ustawa Prawo Ochrony Środowiska z dnia 27 kwietnia 2001 r. (Dz.U. 2001 Nr 62 poz. 627).

21. Wolski P. (2002), Przyrodnicze podstawy kształtowania krajobrazu. Wyd. SGGW, Warszawa.

22. Zielińska A. (2013), Gospodarowanie na obszarach przyrodniczo cennych w Polsce w kontekście rozwoju zrównoważonego. Wyd. UE, Wrocław.

Websites/ Strony internetowe:

23. www.arimr.gov.pl

24. www.coboru.pl 